\section{Celebrating sports physiotherapy specialist: kudos Jacinta Horan (SEPNZ)}

\author{
Blair Jarratt
}

Specialisation - the process of becoming an expert in a particular area of work, study or business; the fact of spending more time on one area of work. Oxford dictionary

\section{MAKING HISTORY}

For the field of sports medicine, 2019 will stand in the history of New Zealand (NZ) physiotherapy. When the NZ Board of Physiotherapy first released the areas of specialisation, the category 'sports' was left off the list. Some argued that sports should sit under the musculoskeletal specialisation area and there would be no need for a stand-alone category.

At that time, the leaders of Sport and Exercise New Zealand (SEPNZ) stood up for all sports practitioners and argued that in its own right it should be recognised as its area of specialisation. Over the years, NZ has watched as other categories of practice gained specialist physiotherapists. In August 2019, the number of specialist physiotherapists was eight. We closed out 2019 with that number rising to nine, with NZ gaining its first-ever sports specialist physiotherapist, Jacinta Horan (see figure 1 for a tweetable image). SEPNZ sees this as momentous victory for all sports physiotherapists, not only in NZ. Jacinta's excellence had provided an example that validates sports and exercise physiotherapy to governing bodies.

\section{WHAT'S IN \#OURBJSM?}

In this SEPNZ edition of the British Journal of Sports Medicine (BJSM), we keep the theme of sport running with one

Correspondence to Mr Blair Jarratt, SEPNZ, New Zealand; blairjarratt@gmail.com of NZ's major sports (although please do not mention the World Cup): rugby. Two infographics (See pages 300 and 298) shows NZ rugby's initiative in the concussion management pathway with the development of a mobile app to inform all key stakeholders. Scottish Rugby doctor Andrew Murray's provides a candid take on how to disseminate your research findings and clinical messages with impact (See page 258). Emotional stories have impact and Peter Stener shares a moving story of what he thought was 'runner's colitis' but what turned out to be much more sinister than that (See page 311). Fortunately, he is now in better shape than ever, thank you for that inspirational 'patient voice'.

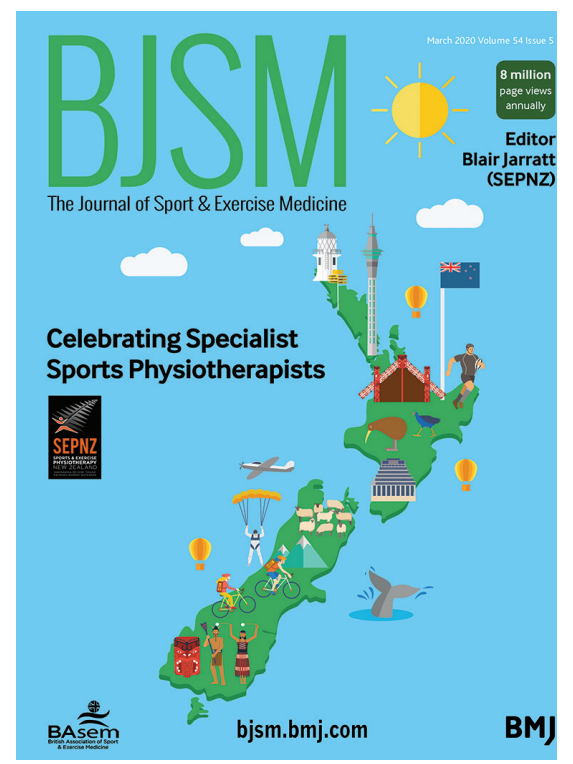

Figure 1 Celebrating sports specialist physiotherapist Jacinta Horan.
BJSM encourages patient involvement in research, and patients with axial spondyloarthritis provided substantial input into the study by Norway's Dr Silje Halvorsen Sveaas (See page 292). High-intensity training (both resistance and aerobic) led to improved function for the disease-specific measures, as well as improved cardiac fitness and strength. Exercise lowered the inflammatory marker. Physical activity seems to be a remarkably effective treatment for a broad range of conditions-a super polypill! In this issue, we see that aerobic training is effective in promoting mental health in patients with noncommunicable diseases, a group known to be at greater risk of depression and anxiety (See page 272).

This celebratory SEPNZ also features the consensus statement on terminology from the most recent International Scientific Tendinopathy Symposium Consensus (10085), which was held in Amsterdam. That group reconvenes in Valencia in 22-24 October 2020. Twitter and Instagram are ISTS_2020. Tendon injury nomenclature continues to be used inconsistently and debate is hot. Is the sport and exercise physiotherapy/medicine community ready to get behind this new consensus?

Cometh the hour, cometh the man/ woman?

Funding The authors have not declared a specific grant for this research from any funding agency in the public, commercial or not-for-profit sectors.

Competing interests None declared.

Patient consent for publication Not required.

Provenance and peer review Commissioned; internally peer reviewed.

(C) Author(s) (or their employer(s)) 2020. No commercial re-use. See rights and permissions. Published by BMJ.

(A) Check for updates

To cite Jarratt B. Br J Sports Med 2020;54:255.

Accepted 30 January 2020

Br J Sports Med 2020;54:255

doi:10.1136/bjsports-2020-102092 